\title{
Voluntad transformadora del sindicato democrático
}

\author{
Manuel $\mathrm{M}^{\mathrm{a}}$ Zorrilla Ruiz \\ Catedrático Emérito de la Universidad de Deusto \\ Ex-Presidente del Tribunal Superior de Justicia del País Vasco \\ Presidente de la Asociación de Jueces y Magistrados Jubilados de España
}

Recibido: 10.01 .2011

Aceptado: 28.01.2011

\begin{abstract}
Resumen: El sistema constitucional español concibe el sindicato como un agente del esfuerzo de transformación requerido para producir el cambio social. La libertad que el sindicato ejerce, debe ser real y efectiva, sin incurrir en vaguedades históricas y comprometiéndose con el espíritu del cambio. La morfología sindical abarca la figura del sindicato clásico, las modalidades asamblearias, las representaciones unitarias y cierta uniones sin personalidad. La transformación significa que el sindicato se apropia los nuevos intereses que, al hacerse visibles, deben promoverse y defenderse para construir una sociedad más igual y más libre. El sindicato realiza esta tarea en conexión con los poderes públicos que, previos los tempestivos controles, apoyan sus iniciativas.
\end{abstract}

Palabras clave: Apoyo, contribución, control, esfuerzo transformador, intereses propios, poderes públicos.

Abstract: The Spanish Constitucional system conceives the labour union as an agent of the transformer effort required to perform the social change. The freedom exercised by the labour union must be real and effective, without incurring in historic vagueness and undertaking the spirit of the change. The estructure of the trade unions includes the figure of the classic composition or delegate democracy, the workers assemblies, the unitary representations and some unions without personality. The transformation means that the trade union appropriates the new interests which must be protected to reach a more equal and free society. The trade union pursuits this task connecting with the public powers which, after the necessary controls, help these initiatives.

Key words: Help, contribution, control, transformer effort, proper interests, public powers.

Sumario: 1. Necesidad, actualidad y entorno axiológico de la tesis que supera la noción simplista de reforma y encarece el significado del esfuerzo de transformación. -2. Particularidades de la condición privilegiada y del carácter de poder cuasipúblico que otorga al sindicato su enclave en el Título Preliminar de la Constitución española de 1.978. -3. Meditaciones históricas que es obligado hacer y operaciones conducentes a intentar la delimitación conceptual del sindicato. -4 . Innovaciones que introducen las variantes de la contribución constitucionalizada de los sindicatos y ejemplos de las peripecias o arbitrios ideados para racionalizar su potencial. -5 . Notabilidad de la doctrina favorable al papel de suplencia que puede 
desempeñar el sindicato en cuanto a la presencia social y el ejercicio de las funciones de los partidos políticos. -6. Hostilidad que el fenómeno mundializador desencadena frente al afán de recobrar la autenticidad e integridad de las libertades sindicales. -7. Diseño constitucional de los modos con que la contribución del sindicato provee a la suerte de los intereses legítimos que, como propios, viene obligado a promover y defender. -8. Envergadura, proyección y difusión de las actividades de contribución sindical. -9 . ¿Se aprecia algún reciente testimonio de la voluntad transformadora del sindicato democrático?

\section{Necesidad, actualidad y entorno axiológico de la tesis que supera la no- ción simplista de reforma y encarece el significado del esfuerzo de trans- formación}

El art. 7 CE (Constitución española de 27 de diciembre de 1.978) -relativo a los sindicatos de trabajadores y a las asociaciones de empresarios- ha despertado una especial curiosidad sobre el papel de los primeros. La doctrina del esfuerzo de transformación -emanada del art. 9.2 CE- les inscribe en la enumeración privilegiada de los grupos sociales o comunidades cuyas libertades deben impulsarse y cuyas demoras se han de eliminar sin paliativos ni pretextos. Este atrevido paso al frente culmina la evolución del proceso que, dejando atrás las libertades formales del Estado de Derecho liberal burgués, preconiza la aspiración liberadora del Estado social y democrático de Derecho. Hay que estimular los adelantos que, fundados en la práctica emancipadora de los sindicatos y en el testimonio de los agentes de cooperación, desencadenen un cambio social más valedero que los ensayados hasta entonces.

El mérito de la pretensión-superadora de las ambiciones que, a su tiempo, restauraron la normalidad democrática europea- obedece al descrédito del concepto de simple reforma y a la sustitución del proyecto revolucionario de los sindicatos - extinto a causa de su desistimiento- por un subrogado de notables repercusiones sociales. Se buscan soluciones que, sin rupturas estentóreas, determinen un giro adaptado a las esperanzas colectivas, consecuente con la dignidad de sus inquietudes, libre de traumas convulsivos e incompatible con la continuidad de situaciones que, luciendo la etiqueta del cambio, poco o nada tienen de transformadoras.

El cuerpo de doctrina informador de estas orientaciones provino del acuerdo tácito impuesto por las circunstancias históricas a los sindicatos y al modelo del Estado social y democrático de Derecho que, al terminar la $2^{\mathrm{a}}$ Guerra Mundial, ambientaba el espacio político europeo. Los sindicatos -en trance de capitalizar unas mudanzas avizoradas a la vuelta de la esquina- acataron, sin merma de su autonomía, los nuevos esquemas constitucionales y aceptaron las reglas de juego con que los promotores de otro estado de cosas les invitaban a entrar en escena. Desecharon el proyecto de revolución inter- 
nacional exterior - trituradora de las instituciones del Estado demoliberal- y abdicaron de las predicciones que, augurando la dictadura del proletariado, llevarían al fin de la Historia. Se reservaron el derecho a incoar las transformaciones sociales que, disociadas de anacronismos notálgicos, nacerían de una revolución pendiente y torrencial a cargo de los poderes de hecho y de Derecho. El transcurso del tiempo pondría las cosas en su sitio y arrojaría luz sobre las perspectivas optimistas de la era del cambio.

Esta dinámica de acción y reflexión descansaba en las pautas con que una original opción del pensamiento jurídico soviético había ensalzado las virtudes de un Derecho nuevo cuyos agentes -entre los que se contaban las organizaciones sindicales- no se limitarían a pacificar los conflictos habidos en el seno de las sociedades. Las causas de una conflictividad desproporcionada y estéril no podían desahuciarse de la esfera social sin los alicientes de una política transformadora que, mejorando las insuficiencias de los modos usuales de composición de conflictos, crease las condiciones necesarias para morigerar las tensiones de los antagonismos destructivos.

\section{Particularidades de la condición privilegiada y del carácter de poder cuasipúblico que otorga al sindicato su enclave en el Título Preliminar de la Constitución española de $\mathbf{1 . 9 7 8}$}

El sindicato se ha erigido en un poder cuasipúblico resuelto $¿$ ? a transformar-sumando un plus de calidad a los intereses generales en pro de los que actua- las anomalías o injusticias de situaciones preexistentes que casi todo lo esperan de su auxilio. Se le considera sujeto de Derecho de Gentes de base institucional, porque carece del soporte territorial de la presencia física que, para el enjuiciamiento de la opinión pública y el aprendizaje de los hechos históricos, requiere el ejercicio de sus libertades. El carácter de sus pretensiones, sus contenidos programáticos y el respaldo de las instancias supranacionales no dieron margen de disconformidad a los Estados soberanos, ávidos de entablar con las organizaciones sindicales relaciones en las que, según el principio de igualdad material, primaban, unas veces, los deberes solidarios de apoyo y, otras, prevalecían las obligaciones cautelares de control. El sindicato -luego de sopesar los inconvenientes y ventajas de dichos contactos- se instaló sin perplejidades ni arrebatos, porque el Derecho de Gentes del Trabajo y el signo de la civilización lo demandaban, en los espacios geográficos subyacentes a la soberanía del Estado.

La autonomía sindical no se pliega al poder del Estado, que acoge de buen grado su funcionamiento y alienta la espontaneidad de sus conquistas, pero el sindicato ha de atenerse a los mínimos de Derecho necesario y de orden público políticoadministrativo - la tranquilidad y la normalidad de la calle que el art. 10.1 CE ha denominado paz social-y respetar las libertades convergentes de que depende el acceso a otras de nueva factura. Lo prueban los arts. 3 II CI (Constitución italiana de 27 de diciembre de 1.947) y 9.2 CE. 
Coexisten dos ordenamientos jurídicos - de base territorial e institucional respectivamente- en los que, de una parte, la soberanía estatal y, de otra, la autonomía colectiva sindical derraman las regulaciones dictadas por las potestades normativas competentes para convertirlas en Derecho objetivo, desenvolverlas, aplicarlas y hacerlas cumplir. Sus relaciones se asemejan al marco de las propuestas y contactos que, según los modos de entender el alcance de sus vinculaciones, se juzgaron históricamente adecuados para flexibilizar la colaboración de los poderes seculares con el poder eclesiástico. Las acciones estatales de control y las medidas oficiales de apoyo garantizan las modalidades de interacción y las preferencias fiables de un equilibrio duradero. Las unas evitan que, a falta de un prudencialismo preventivo, el frenesí del sindicalismo democrático -cautivo de la tentación totalitaria o de otras claudicaciones censurables- esquilme los atributos capitales de la soberanía política. Las otras reprimen los menoscabos de la autonomía con que la tenacidad del sindicato denuncia los comportamientos que vulneran la esencia de sus libertades. Las clásicas nociones de policía, fomento, servicio público y gestión económica integran, por desiguales partes, el reducto de las relaciones de los poderes oficiales con el universo sindical.

$\mathrm{El}$ art. $7 \mathrm{CE}$ alude a una libertad de asociación empresarial que sólo ha provocado una atención discreta, porque los compromisos del esfuerzo de transformación no se enderezaban a exaltar la causa de los empleadores, ni mediaban argumentos de peso para acometer iniciativas de ese corte. Otra cosa es que, ante lo convulso de una crisis económica más estructural y recurrente que coyuntural y transitoria, las funciones sociales de la libertad de empresa-que el art. $38 \mathrm{CE}$ predica del regular funcionamiento de la economía de mercado y no de los atropellos del liberalismo salvaje- merezcan atenciones que poco o nada tienen de propósito salvífico. La cláusula transformadora y social del art. 9.2 CE invita a examinar, desde las atalayas sindicales, un haz de conceptos jurídicos indeterminados que acreditan lo sagaz y fructífero de las interpretaciones respaldadas por el valor superior del pluralismo político. Amén de que, gracias a un protagonismo novedoso, el sindicato pase a residir en el TPCE (Título Preliminar de la Constitución española), las variantes de su actividad se reconocen como derechos fundamentales y reciben el tratamiento que la sec. $2^{\mathrm{a}}$, cap. $2^{\circ}$, tít. I CE dedica a su protección y desarrollo. El constituyente incurrió en el defecto -contextual y sistemático- de que el TPCE silenciase las especies colectivas de intervención sindical, aunque art. 28.1 CE haya enmendado la omisión sólo en parte. De haberse dado una redacción exhaustiva y exacta, sobrarían las precisiones que, para rellenar esa laguna, se han hecho más tarde.

Un cuerpo de doctrina solvente y responsable adjudica al TPCE la etiqueta jurídica de pasaje privilegiado, no en la acepción tradicional de una excepcionalidad irrepetible, que suspende la generalidad de la ley, y sí a los efectos de certificar la impronta del espíritu de cambio. La audacia de su testimonio impregna los principios y/ preceptos siguientes de la carta política, a 
fin de que esta introducción sirva de criterio auténtico de interpretación de las normas de Derecho Positivo que, quiérase o no, se sensibilizan a los toques de atención del progreso. El privilegio implica que los iconos del TPCE pueden asistir a cuantos acontecimientos se subsuman en las regulaciones de la legalidad fundamental y afecten a intereses que dependen de los actos legítimos de apropiación relacionados con la idea de servicio o las vivencias del sentimiento constitucional. La referencia al sindicato responde a estos modos de ver y razonar. Al manejar los preceptos aplicables a los distintos supuestos en que resplandece la acción combativa de los sindicatos, ha de primar la oportunidad deparada por la lectura-imaginativa y global- del TPCE y estarse a lo que, enalteciendo la causa sindical, es, significa y representa su cualidad privilegiada. Cuando las reivindicaciones sindicales toleran comprensiones equívocas o alternativas, prevalecen las que -frente a las escudadas en una tozuda voluntad inmovilista- aportan apreciables mudanzas de las libertades que van a enriquecerse.

El objetivo de establecer una sociedad democrática avanzada se remite a un futuro costosamente imaginable ante la estupefacción que produce la singularidad del doble prefacio de la carta política. A saber, el que forman el Pr.CE (Preámbulo de la Constitución española) propiamente dicho y el TPCE. Una objeción que no se salva con evasiones anecdóticas, porque es patente el dedo acusador de los pasajes que convencen de que el interrogante sigue ahí y aguarda el parecer de cuantas mentes asombradas intuyen los problemas que, congelados de presente, pueden surgir más tarde o más temprano. ¿Acaso hay mecanismos de efecto retardado que sigilosamente aguardan sus oportunidades explosivas en la intimidad del texto constitucional?

La cointegración de ambos elementos interpretativos no es gratuita y, aun constando el ajetreo de ponerla en marcha, se ha de tener en cuenta. El TPCE, línea de salida de la carrera de desvelos emprendida por los fundadores de la carta política, condensa -junto a sus novedades- las clásicas inspiraciones y los principios transaccionales que, en el curso del tiempo, suavizan o entumecen los modos de entenderlos. La invención del consenso -hoy reemplazada por el cultivo y la publicidad de la memoria histórica- no se compagina con ciertos aspectos esenciales de la seguridad jurídica que el art. 9.3 CE dice garantizar. ¿Qué juicio merecen las enmiendas extravagantes venidas de corrientes ilustradas a las que quiso resarcirse del daño consistente en su exclusión del cuerpo de juristas autores de la carta política? Los así marginados de la redacción del texto prologado o parte dispositiva de la CE, lograron una entrada -complaciente y tardía- de inofensivas apariencias. Cada una de ellas era una dec. Pr. CE (decisión del Preámbulo de la Constitución española). Para calmar la irritación de los agraviados por la enemistad política o los celos dogmáticos de los intervenientes de origen, se formó una comisión adicional que antepuso al texto constitucional el que, bajo la rúbrica de Preámbulo, afirmaba la voluntad de establecer la sociedad democrática avanzada que la dec. 5 Pr. CE predecía. Los autores directos de la ley fundamental renunciaron a 
redactar la introducción y, accediendo a una forma híbrida de compensación, aceptaron que ese proemio fuese obra de juristas extraños a la paternidad de una norma jurídica en cuyas páginas no habían estampado una sola tilde en negro sobre blanco. Rebasando los límites del esfuerzo de transformación, alentaron la esperanza puesta por algunos de ellos en el regreso a las utopías del marxismo camuflado tras un inédito artificio de decoración legislativa. La legalidad fundamental podía reducirse, pasando sobre ascuas, a un instrumento transitorio del cambio enmascarado en la proposición de la dec. 5 Pr. CE. El profetismo colateral ha sucumbido al concluyente enclave del TPCE, inconfesada e inequívoca Exposición de Motivos que, desde un principio y para aviso de caminantes, encabeza la parte dispositiva de la CE.

¿Hasta dónde esta ocurrencia respetaba el valor superior del pluralismo político y hurtaba al conocimiento de la opinión pública los peligros de fracturar la imagen de la CE? Su defensa requería propuestas comprensibles, cautivadoras del entendimiento y la emoción, homogéneamente divulgadas y exentas de solicitudes ambiguas. Ajenas al camino insinuado en la dec. 5 Pr. CE para tonificar el espíritu de cambio y el invento de revolución interior que, como obligaciones naturales de los poderes públicos, vaticinaba el mensaje del art. 9.2 CE.

\section{Consideraciones históricas que es obligado hacer y operaciones que han de examinarse para intentar la delimitación conceptual del sindicato}

$\mathrm{El}$ art. $7 \mathrm{CE}$ suscita el tema de la delimitacion conceptual del sindicato que, como toda comunidad procedente de decisiones claras y tenaces, emerge y progresa a partir de una colectividad anterior o agregación mecánica de personas físicas. Lo irresistible de los acontecimientos las aprisiona en un ámbito de intereses -conglomerado de apetencias que discurren en pos de bienes útiles- y les impide desentenderse de sus nexos con la curiosidad del pensamiento y las inquietudes del bienestar general. Sus pobladores -entregados a tareas idénticas o semejantes- advierten cómo, con visos de continuidad y duración, comparten vivencias o acarician proyectos comunes, a cuyo crecimiento -saboteado por las legiones de los enemigos del progreso- no pueden renunciar sin que, de por vida, les persiga la certeza de haberse condenado a muerte moral.

La figura del sindicato -arreglado a las pautas de la democracia delegada- surgió del concierto que, para repartirse el botín incautado a los totalitarismos reaccionarios, estipularon las potencias victoriosas en la $2^{\mathrm{a}}$ Guerra Mundial. Los movimientos sindicales se desdijeron de unas vías revolucionarias tan azarosas de trazar como enconadas de seguir. Advirtiendo los pros y los contras del cambio de rumbo, decidieron jugar el papel de interlocutores válidos de los poderes públicos en los países industrializados con economía de mercado, donde se abrían tentadores escenarios económicos que enriquecían la lógica de los objetivos sindicales. El Estado democrático de 
nuevo cuño socializó los derechos individuales de corte clásico, constitucionalizados por el Estado demoliberal y devenidos luego derechos-función de estimulante contenido. Elevó a la categoría de intereses vestidos o derechos subjetivos sociales los que, como intereses desnudos o ayunos de tutela jurídica, propugnaban los sindicatos celosos de su advenimiento al campo de las relaciones individuales y colectivas de trabajo. Obtuvieron la protección que, junto a su núcleo invulnerable y/o sus connotaciones periféricas, garantizaba el acceso a la jurisdicción para dilucidar los conflictos nacidos de sus incidencias. Se puso fin a la demonización de la judicatura que, según los reproches de la voz sindical, no ocultaba su estirpe burguesa y paralizaba los arrestos del Derecho inspirado en una Política Social moderna y agresiva. La recriminación no era de ayer y se sumaba a los denuestos que, en coyunturas similares, los sindicatos habían dedicado al universo hostil que componían las confesiones religiosas de su tiempo, la milicia, la aristocracia y los banqueros.

El ordenamiento jurídico del sindicato se asemeja al del Estado soberano, aunque las potestades oficiales de control entrañen algunas diferencias. Control que, luego de ejercitarse toscamente, se tecnifica y pasa a ser un aspecto básico del derecho fundamental a la efectiva tutela judicial de situaciones conflictivas en que -mediante respuestas razonables y jurídicamente motivadas sobre el fondo de los problemas litigiosos- se declara cómo y hasta dónde los sindicatos deben ejercitar, con arreglo a Derecho, sus libertades naturales. También han de acatar las normas dictadas por los poderes públicos para salvaguardar los mínimos de adecuación al Derecho necesario -textual o virtual- que ineludiblemente les conmina.

El Estado social de Derecho cumple un deber sobrevenido cuando, proveyendo a la recepción del sindicato, le dispensa su ayuda para forjar una civilizada coexistencia - purgada de antagonismos anacrónicos- y apoyar sus buenos oficios de contribución. Uno de ellos consiste en mejorar, gracias a la negociación colectiva, las condiciones contractuales de trabajo y acordar las novaciones cíclicas que -en virtud de una eficacia frente a todos, homóloga de la generalidad de las leyes- reponen el equilibrio roto por el abuso de los poderes de organización y dirección que los empresarios ejercitan. Dicha negociación restaura, durante un período de tregua o paz social sensatamente establecido, la conmutatividad o equivalencia objetiva de las prestaciones que -a diferencia de las especies gobernadas por el principio de autonomía de la voluntad y la equivalencia subjetiva de aquéllas- se predica de la naturaleza de las relaciones individuales de trabajo.

La implantación sindical presta el arraigo que contribuye a defender, en la parte que le toca, el orden político y la paz social de que hace mérito el art. 10.1 CE. Uno y otra afianzan la cohesión de la sociedad pluralista -conjurando los riesgos de su disolución y/o retroceso- y aseguran la continuidad de la dación de bienes y servicios al mercado de libre competencia. Contribuir no sólo significa que se ha de actuar en consonancia con otras instancias so- 
ciales y políticas, sino también que el ejercicio del poder sindical -encaminado a conseguirlo- no constituye el cumplimiento de una obligación de fines o de resultado. Nace de una obligación de medios o de simple actividad que, al pactarse la tregua normalizadora de las relaciones industriales, trasluce el esfuerzo con que el ascendiente del sindicato representativo intenta que otras organizaciones sindicales - menos arraigadas- se adhieran a sus compromisos pacificadores. El fracaso de la contribución no es imputable al sindicato que -a la luz de las particularidades de los protagonistas, del tiempo y del lugar-consiga probar cómo, pese al agotamiento de las dosis de atención y cuidado peculiares de la diligencia exigible, su designio fenece ante lo insuperable de las trabas que impiden o dificultan sumamente el buen fin de sus actividades de influencia.

Las estrategias y los desencuentros sindicales han dado lugar a que el ejercicio del deber de paz se convierta en un ente de razón frente al cúmulo de imponderables y fuerzas mayores que entorpecen su efectivo cumplimiento. Se diagnostica un proceso de desigualación que empobrece e inhibe los ímpetus de la ambición transformadora. La negociación colectiva -pieza básica del orden nuevo de las relaciones industriales- aumenta las cargas de los empleadores, urgidos a cumplir íntegramente la parte normativa de los convenios, y aligera las de los sindicatos representativos que, sin apenas incomodidades, se desligan de la parte obligacional de esos acuerdos.

La irrupción del modelo de sindicato clásico en el Estado social y democrático de Derecho alentó la ida en pos de las ventajas cuantitativas y dio paso al aburguesamiento de la clase trabajadora que, renegando de sus orígenes históricos, se embarcó en la aventuras de un frenético estallido consumista que el adoctrinamiento sindical no desautorizó ni dejó fuera de juego. Se adujo que esas satisfacciones compensaban los pasados sacrificios -tendentes a forjar el utópico fin de la historia- y que la clase trabajadora, huérfana de la protección pedagógica de un sindicato inmune a los reproches de su mala conciencia, se eximía de las obligaciones cualitativas que aun formaban el bloque de sus asignaturas pendientes.

La permisividad del sindicato tradicional erosionó la conciencia de clase de los trabajadores y aniquiló buena parte de sus aspiraciones. Se prefirió el prestigio inmediato de esas utilidades al crédito aplazado de un incierto futuro. El romántico encanto de las utopías quedó atrás, como si hubiese corrido la suerte de un envejecido cachivache. No se advirtió que, lejos de estabilizarse, la situación sólo perduraba mientras las riquezas extractivas de las explotaciones coloniales o cuasicoloniales asegurasen, mediante una competencia soportable, los márgenes aceptables de beneficio industrial. Los sindicatos se valieron de esta circunstancia para ceñirse a intervenir como agentes de gestión-favorecidos por el estreno de la reciente Política Social de los Estados soberanos- y rehuir los escenarios álgidos de la confrontación o el desafío. El capital elogiaba -como expresión elocuente de progreso- las inclinaciones consumistas que, lejos de animar los pasos al frente de una Política Social equitativa, minaban las energías morales del mundo del trabajo y le alejaban 
de unas metas que, pendientes de alcanzarse, se olvidaban definitivamente o se relegaban a un segundo plano.

El enardecimiento sociopolítico del principio de autodeterminación de los pueblos fulminó la explotación de los modelos coloniales y cuasicoloniales, terminó con el aprovisionamiento abusivo de los bienes de producción, agravó las dificultades de sustituirlos, aumentó las fricciones de la competencia y, para sortear tantos y tan enojosos escollos, encendió la pavorosa mecha de las técnicas de racionalización. Se debieron éstas a la necesidad que asediaba al factor-capital- de no quedar al margen de los mercados de libre concurrencia, donde las fuerzas de la producción más precavidas usaban de la tecnología para evitar su expulsión y descartar los riesgos que obstaban a la consecución del beneficio. Invocando las razones del culto a la productividad, crecieron inhumanamente los ritmos de trabajo y las obligaciones de medios de los trabajadores se degradaron a cuasiobligaciones de resultado dependientes de las cifras de bienes y/o servicios ofrecidos a los consumidores. Sin suavizarse un ápice la acritud de las relaciones colectivas, la fatiga industrial apareció asociada al sistema de la remuneración por incentivos. Los trabajadores pasaron a ser, para su desventura, cómplices inconscientes de la explotación que padecían. Se reprodujo y elevó a la segunda potencia el reproche marxista que denunciaba cómo, lejos de que la personalidad del autor trascendiese a la impresión y visibilidad de la obra bien hecha, impregnando su totalidad, el trabajador se relacionaba con el resultado de su esfuerzo como con un producto extraño.

El sindicato clásico cuidaba de los intereses colectivos cuya vigencia y suerte radicaban en los grandes ámbitos donde se pregonaban y ejercían sus reivindicaciones. Carecía de preparación para velar por los intereses colectivos de empresa o centro de trabajo que -ante el progreso transmitido por las adquisiciones de la economía de la guerra a las demandas de la economía de la paz-emergían en los lugares de empleo, a los que la teoría y la práctica del conflicto industrial habían trasladado los escenarios emblemáticos de sus futuros desencuentros. El aumento de los ritmos de actividad pugnaba con la naturaleza jurídica de un deber individual de trabajar que, sin atender a las aptitudes específicas del trabajador, se supeditaba a la severidad de los módulos racionalizadores. La atribución a las personas físicas de la cualidad de ciudadanos de segunda zona atentaba contra su dignidad y vulneraba sus derechos fundamentales en el lugar de empleo. Quebraba la equivalencia objetiva de las prestaciones contractuales, castigadas por las servidumbres de una productividad que, al compendiar los fundamentos métodológicos del cambio y lo evidente de sus males, daba cuenta de su fisonomía demoníaca. Las primitivas estructuras sindicales cedieron parte de su protagonismo a las especies de delegación sindical y de representación unitaria -en las empresas o centros de trabajo sujetos a los sistemas de racionalización productiva- que los conceptos jurídicos indeterminados del art. $7 \mathrm{CE}$ han sugerido para internarse en los parajes de la expansión transformadora. 
Un objetivo de este sindicalismo era proteger a sus representantes frente a las demasías tecnológicas que, escudados en las potestades de organización y dirección, los empleadores manejaban con delectación digna de mejor causa. Los excesos de la obnubilación productiva y el culto al rendimiento se enfrentaron a las tentativas de acceso a la participación y a las demás reivindicaciones con que la democracia industrial individualizaba sus caminos propios. El universo de las relaciones de trabajo comulgaba con el sistema de vivencias que un enfebrecido sentimiento democrático difundía también a la familia, a las confesiones religiosas, a los espacios universitarios y a los grupos organizados de la sociedad pluralista que mostraban espectaculares adelantos. Se intuían entonces los propósitos de edificar un mundo nuevo y apegado a las novedosas consignas de la contestación.

Auspiciando la gran esperanza del art. 9.2 CE, el art. $7 \mathrm{CE}$ acoge el $e x$ perimento asambleario que, como forma incipiente de democracia directa sindical, precedió a la institución de las representaciones unitarias. La lucha de clases no había terminado con la renuncia sindical a la revolución y apremiaba adueñarse del poder social mediante operaciones que la ceguera consumista de la clase trabajadora situaba al margen de su contexto de progreso. No se avenía a corregir la indiferencia de un sindicalismo volcado en menesteres de gestión y refractario al testimonio de los enfrentamientos sistemáticos.

El apoyo de los intelectuales y las comunidades universitarias era indispensable para consolidar la recepción real y efectiva del modelo del nuevo sindicato. Toda una aventura de sindicalismo ilustrado en que las precipitaciones de la acción sofocaron la serenidad del pensamiento. Aunque la iniciativa perduró en los órganos de representación afines a la democracia directa en los lugares de empleo, su vigor decayó a causa de circunstancias desalentadoras. A saber, el desgaste de la dedicación de los movimientos asamblearios a tiempo completo, la imposibilidad de fraguar una metodología persuasiva para tomar las decisiones en tiempo razonable y no aplazarlas demasiado ni asumirlas sin ponderar los inconvenientes de los excesos de emocionalidad, y el miedo a ganar si se conquistaba un poder cuyo ejercicio acarreaba responsabilidades expuestas a frustraciones estridentes.

No es fortuito el tiento con que el art. 129 I CE apura el indicativo sindical del art. $7 \mathrm{CE}$ y anuncia que los poderes públicos promoverán eficazmente las diversas formas de participación en la empresa. Esta proclamación -cobijada bajo el rótulo Economía y Hacienda (tít. VII CE)- legitima las variantes más dinámicas de sindicalismo y encierra un ingrediente de prudencia que, lejos de originar demoras, afianza la admisibilidad de las versiones sensatas del esfuerzo de transformación. La eficacia no equivale al resultado de una ocurrencia respaldada, sin apenas espíritu crítico, por quién sabe qué demandas sociales. Depende de una racionalización densa y pausada que incluye el estudio de su naturaleza y el cómputo de los resultados obtenidos. Requiere convencerse, desde el comienzo de la operación transformadora, de que, ade- 
más de incoar experimentos guiados por intenciones óptimas, hay que prever las consecuencias de la participación que se incentiva. No tanto se encara un sindicalismo dual, expuesto a disgregaciones e incoherencias, cuanto un sindicalismo ascendente que apuesta por formas imaginativas de progreso. Una de ellas, en cuanto máximamente participativa, prueba la efectividad-elevación de la eficacia a la segunda potencia-de los actos de decisionismo politico con que el legislador ordinario elige soluciones genéricamente razonables y específicamente preferibles para atender, llegado el caso, a las demandas sindicales.

\section{Innovaciones que ofrecen las variantes de la contribución constitucio- nalizada de los sindicatos y ejemplos de las peripecias o arbitrios idea- dos para racionalizar su potencial}

Un aspecto notable de la constitucionalización del sindicato es que sus diversiones -serie de facultades englobadas en la libertad pública que se le adjudica- dependen de conductas observadas en régimen de contribución. La elección del verbo típico de esta actividad no es casual, como ocurre también con la dicción que el art. 52 CE dedica al principio rector de la Política Social y Económica en tema de actividades corporativas. La enjundia de los cambios sociales proscribe la frivolidad de atribuirlos a los comportamientos de un único agente que puede pecar de arrogancia, escudarse en eventos externos o aceptar la realidad de su fracaso. La idea de la contribución del sindicato recuerda lo imprescindible de otras asistencias para defender sus intereses peculiares o inmiscuirse en la evolución de los procesos cuyos éxitos se aprovechan de esa peculiar injerencia. El sindicato no está llamado a continuar la ruta incierta de un navegante audaz y solitario, y sí a beneficiarse del apoyo de los poderes públicos y de las comunidades asentadas en las zonas manifiestamente mejorables de la sociedad pluralista que se complace en acogerle.

El sindicato es uno de los poderes de hecho o instancias cuasipúblicas que vertebra el equilibrio institucional del Estado de las autonomías e impide su dislocación. No en vano los arts. 2, 45.2, 138.1 y 156.1 CE declaran indispensable la solidaridad colectiva en un doble concepto. Subjetivamente, porque la falta de solidaridad y el desdén de las virtudes que la totalizan, revelan -como antaño apuntó sagazmente la ciencia canónica- un empecatamiento constitucional que destituye de su dignidad a cuantos se abstienen de socorrer esa indigencia. Objetivamente, ya que los mecanismos de causalidad -cuya regularidad debe producir efectos elogiables- decaen, por menos consistentes, si el crédito de la solidaridad adeudada no acompaña a sus intervenciones. El sindicato se erige en agente principal o coadyuvante de la tutela de los intereses acreedores al celo del esfuerzo de transformación. Cosa distinta es que los mensajes de la dec. 5 Pr.CE y el art. 7 CE se perviertan, trivialicen o reduzcan a claves que, sin interpretaciones de fuste, amalgaman los pensamientos débiles y las ofuscaciones que causan. 
Un testimonio de solidaridad residiría en la coincidencia reivindicativa de los sindicatos frente a los desafíos o males que postulan remedios urgentes y a prueba de fracaso. Por desgracia, las cosas no han ocurrido de este modo. Frente a la lógica de lo sensatamente presumible, los sindicatos compiten para situar en el mercado un producto social de calidad y variedad óptimas, y adquir un prestigio que desplace al de las demás organizaciones concurrentes. ¿Se asemeja este dato a las proposiciones - pasadas y temiblesque, sobre el destino sobrenatural de los seres humanos caídos en el mundo, sostenían que "fuera de la Iglesia no hay salvación"? En trance de exhibir sus recursos y copar los centros de poder que acrecienten su popularidad, los sindicatos no tienden -salvo en las situaciones-límite que agrupan las estrategias defensivas o las oportunidades cualificadas de victoria- a formar con otros sindicatos coaliciones ideológicas que refundan las particularidades de sus ofertas respectivas. Ligados por la comunidad de pensamiento y aceptación de unos valores generales, disienten -a veces, acaloradamente- en cuestiones que, pese a tales diferencias, pertenecen a un cuerpo de doctrina común. Pretenden que la excelencia de las cualidades de sus propósitos y resultados cautive las predilecciones que, adheridas a la más sugestiva de esas fórmulas, les doten del poder consustancial a su audiencia, su implantación, su representatividad y su arraigo. Etiquetándose de portadores de un ascendiente social de máximo calibre, los sindicatos representativos acopian dosis crecientes de prestigio que superan a las de las organizaciones sindicales menos acreditadas y con las que no están dispuestos a compartir su ventajosa posición.

El sindicato es uno de los grupos sociales que, según el art. 20.3 CE, acceden significativamente a los medios públicos de comunicación social, donde la libertad de expresión adereza la libertad sindical y prevé la conformidad o el desacuerdo con otros criterios concurrentes. La cordura aconseja usar con prudencia de la facultad de disentir y evitar posiciones extremas que acaso la confundan con el río revuelto de los radicalismos estériles. La contribución sindical, preceptuada en el art. $7 \mathrm{CE}$, reconoce unos orígenes históricos que, ante las compulsiones de la lucha de clases, no prejuzgan la contrapartida de un sindicalismo rotundamente solidario. A partir de su entrada en escena, el sindicato se compromete a defender la excelencia de unas soluciones que considera salvíficas para el porvenir de la sociedad pluralista y de las comunidades componentes. Fuera de los sindicatos de máximo arraigo, no cabe aprovechar óptimamente los frutos de las victorias intersindicales libradas en pro de esta causa. La intervención sindical -impregnada de solidaridad en la negociación colectiva- demuestra el ímpetu de los sindicatos que esgrimen, frente a todos, los valores y el ímpetu de su autonomía soberana.

La ambientación históricopolítica del sindicato da cuenta y razón de sus objetivos capitales. Agota sus procesos de inserción en la sociedad pluralista que le dota de espacios habitables, supera las adversidades que le afligen, se empeña en mejorar su regular funcionamiento y, consciente de las demandas sociales verdaderas y no artificiosas, propone a sus destinatarios- que no 
siempre coinciden con el círculo de los trabajadores dependientes o servidores públicos asimilados- los beneficios justos o el pago de las deudas históricas pendientes de satisfacer.

La espontaneidad del sindicalismo asambleario activó la experiencia de una negociación colectiva desvinculada o acrática, cuyos corpúsculos sindicales -más obedientes al impacto emocional que al raciocinio equilibrado-copiaron los modales de la esfera política. Introdujeron una autonomía colectiva que decía proteger intereses preseleccionados y expuestos, según sus valedores de ocasión, a graves peligros y/o agresiones. Algunos de ellos -fruto de una imaginación calenturienta- no vacilaban en sindicalizar cuanto se oteaba en el horizonte de su fiebre de selectividad. Tales descubrimientos no tenían una razón de subsistir distinta de la de sus pretensiones efímeras. Lejos de encarnar los aciertos de una autonomía emprendedora, surgían -como contrafigura del ingenio creador y responsable- al calor de un pensamiento enfurecido y débil. Sus testimonios -contraculturales y anecdóticos- poco han aportado al debate sobre los aspectos del esfuerzo de transformación que sus innovaciones invocaban.

La fenómenología sindical comprende la figura de las uniones sin personalidad que -aunque las razones de urgencia dificulten el tecnicismo de personificarlas- defienden intereses cuya naturaleza exige protegerlos con los instrumentos que intuitiva e instintivamente se adivinan. El crédito de estas operaciones -regidas por la honestidad y la clarividencia sindicales- depende de los resultados habidos en el breve curso de su ejecución, tras la cual se deshilvana el interés en juego. Su fundamento, lejos de ser insustancial o arbitrario, está en la propensión al imperio de la justicia material transmitida por el constituyente al sindicato responsable que hace gala de su fidelidad al llamamiento del art. 7 CE y a su privilegiada impostación en el TPCE.

El sindicato contribuye con los poderes públicos cuando su intervención condiciona la suerte de intereses que, como propios, resuelve tutelar según la máxima de que "nada de lo que ocurre entre los hombres es ajeno a las voluntades defensivas del bien y la justicia". La Ciencia de la Legislación o Política Legislativa acierta destacando el relieve de ciertos intereses generales, seleccionando sus emplazamientos históricos y cancelando los entorpecimientos opuestos a su atribución y disfrute. El sindicato -propagador de inquietudes extendidas a los espacios sociales y políticos afectados por su poder de decisión- percibe, integra y conduce los afanes cuyo acceso a la vida general de relación se juzgaba excepcional o extemporáneo, aunque de presente haya resultado no serlo. La presión sindical puede alertar sobre los apremios de ordenación legislativa ignorados por los grupos sociales, cuando no testarudamente silenciados o proscritos por el empecinamiento de las predilecciones políticas. El exhaustivo acopio de los datos que individualizan las dimensiones de cada problema y le adaptan al espíritu móvil del Derecho Social, compete a un sindicato enterado de su envergadura frente a la apatía con que se conducen otros actores de la vida pública. 
También se habla de la función colegislativa de los sindicatos que extraparlamentariamente convienen con el Poder Legislativo soluciones que -sometidas a una elaboración complaciente y sin apenas generar debateadvienen al sector social del ordenamiento jurídico. Dichas intervenciones se difunden a cuantos temas de proyección social adopta el sindicato como intereses propios que agigantan los espacios de su autonomía. Olvidándose de la omnipotencia soberana del Poder Legislativo, la jerga sindical les da el nombre de leyes pactadas, porque la compulsión del sindicato doblega el hieratismo de unos legisladores que -diciéndose técnicamente irreprochables-renuncian equitativamente $(i$ ?) a serlo. Recuérdense los requisitos que $-\mathrm{al}$ quebrar el principio de irregresividad de las adquisiciones sociales $\mathrm{y}$, con él, derribarse la consigna "siempre más, nunca bastante"- impuso el yusnaturalismo democrático para paliar los álgidos efectos de ese retroceso. Se precisó un acuerdo de los sindicatos con el poder del Estado que, encarnado en la soberanía parlamentaria, interpretó lúcidamente la trascendencia del cambio producido. Se estableció la obligación de indemnizar el daño causado por la privación de unos derechos sociales que -adquiridos colectivamente y pese a las apariencias de regularidad expropiatoria- sufrieron el calvario de la confiscación. Se señalaron plazos para dulcificar los sacrificios del tránsito a una Política Social de la flexibilidad, cuyos impunes extravíos se vislumbraban desde entonces.

Aunque los sindicatos no participen formalmente en el procedimiento de elaboración de las leyes, su parecer ha de tenerse en cuenta si, con ese motivo, surgen problemas que atañen a sus intereses propios y la ley -que debe regularlos- corre el riesgo de verse tocada del ala por las insuficiencias de justicia material que maltratan su finalidad y su espíritu. Las tensiones entre los criterios de un Parlamento partidario de regular la huelga y el dogma sindical de que la mejor ley de huelga es la que no existe, ejemplifican las opciones ambas constitucionales- relativas a una toma de posición legislativa que se aplaude o se desautoriza. La contribución del sindicato equivale a una cooperación crítica cuando ilustra a la opinión pública sobre los designios -acreedores a la censura o el elogio- del legislador o, para presionarle desde el exterior, invita a ejercitar los derechos fundamentales de reunión y manifestación. El art. 21.1 CE los pone al servicio de la libertad sindical mediante las expresiones de la voluntad colectiva que robustecen su núcleo invulnerable.

Sería óptimo que el juego absolutamente limpio -difícil, ya que no imposible, de aplicar a la racionalización moral de la vida política-inspirase la contribución del sindicato a la legislación, sobre todo si las realidades sociales del tiempo y del lugar avalan su necesidad. Esta contribución brilla por su ausencia si -tras haber elogiado las instituciones competentes la participación sindical, a la vera de los poderes públicos, antes de debatirse, por citar un ejemplo, proyectos de ley relevantes para los intereses de los trabajadores-el sindicato confiesa, ¿con desidia intencional o apariencia de candidez indigerible?, que de tales extremos no está más informado que el resto de la ciuda- 
danía. Como si poco o nada contasen los deberes sindicales de aplicarse a la hechura y control de los experimentos de esa traza.

La carga de la contribución sindical alcanza a las competencias del Poder Ejecutivo que, según el art. $97 \mathrm{CE}$, dirige la Política Social como parte de la Política Interior de relaciones con los sindicatos. Tienen éstos derecho a divulgar su parecer sobre cuantos supuestos, gestionados por aquel poder público, forman parte de los intereses generales que inmediatamente les conciernen. Intereses que, como reza el art. 103.1 CE, las Administraciones Públicas han de servir con una objetividad que, muchas veces, se soslaya o es difícil de poner en claro. La contribución sindical de saneamiento abarca la enumeración de las disidencias preventivas, la denuncia de las irregularidades que el Poder Ejecutivo puede cometer, las propuestas de remedios atinentes a las competencias gubernamentales y la lista de las anomalías transmitidas a la opinión pública para que reaccione ante la información veraz que se le suministra. La prerrogativa sindical de ingerirse en el círculo de esos intereses es ilimitada, pues, a la luz del art. $7 \mathrm{CE}$, su apertura irrestricta se debe a la presunción de la clarividencia del diagnóstico que a la sazón emite el sindicato.

Más delicado es el tema de la contribución sindical con el Poder Judicial que define el art. 117 I CE. ¿Se reputan sindicalmente propios ciertos intereses que el Poder Judicial -sometido exclusivamente al imperio de la ley-garantiza y que los sindicatos gestionan conforme al albedrío impredecible de sus libertades? Antes de renunciar a la revolución pensada para reducir a pavesas el Estado demoliberal, los sindicatos abrazaron, como un lema de sus ofertas culturales, la consigna de pulverizar las instituciones de un Poder Judicial incapaz de insertarse, a causa de su cepa burguesa, en las contradicciones de una sociedad aherrojada por la supuesta antisocialidad de su formación y sus pronunciamientos. Una judicatura que, al apostar por los derechos individuales de libertad y propiedad privada, malinterpretaría la emocionalidad colectiva de la lucha de clases que el Estado confundía con los fenómenos de alteración del orden público. Una judicatura que, como ya se ha recordado, se identificaría con el conglomerado de enemigos de la clase trabajadora a que pertenecían los eclesiásticos, los militares, la aristocracia y los banqueros.

Olvidada de estos reparos anacrónicos, la conciencia sindical ha entendido que su contribución a la efectiva tutela judicial de los intereses legítimos de los trabajadores es una más de las atenciones que el sindicato les adeuda. Se robustece así el ejercicio de las libertades sindicales a que alcanza dicha protección. El amplio espectro del art. 24.1 CE permite judicializar, gracias a la eficacia y justicia del orden natural de la equidad, la suerte de los intereses desnudos -carentes del empaque de los intereses vestidos accesibles a la jurisdicción- y desvirtuar las objeciones que minusvaloran una oportunidad de este calibre. Cuando la autonomía de la resistencia sindical no logra contener los abusos de los empleadores, el proceso represivo de conductas antisindi- 
cales suple la frustración de las reacciones que el sindicato no completa con el éxito que merecían la sinceridad y rectitud de su intención.

Las rudimentarias estructuras de los sindicatos de interés irrepetible y único se benefician de la innovación del art. 24.2 CE e ingresan en el círculo tutelar de la jurisdicción, aunque no se hayan agotado las oportunidades que ofrece esta fórmula. La fuerza vinculante de la negociación colectiva, sancionada en el art. 37.1 CE, refleja la cooperación sindical al funcionamiento regular de uno de los poderes del Estado social y democrático de Derecho. Al aplicar e interpretar las normas de un ordenamiento jurídico extraestatal, la jurisdicción aclara las dificultades que, habidas en su seno, conviven con las que los modos extrajudiciales de composición de controversias ayudan a desvanecer. Modos que invaden velozmente los campos del Derecho objetivo en que la judicialización de los conflictos se resiente de sus incorregibles dilaciones y de los sacrificios económicos a que da lugar.

La naturaleza del conflicto industrial -embebido en la lucha de clases-y el signo revolucionario de sus primeros tiempos, oscurecen la concreción del momento histórico en que se intuye la necesidad de que los sindicatos cooperen a tutelar los intereses compartidos por ellos mismos y por los empresarios. El dogma de irreversibilidad de las adquisiciones sociales -anejas a una etapa emblemática de las relaciones de trabajo- compaginaba la distensión del conflicto industrial con el convencimiento de que, sin jactarse de la victoria final del sindicato, la negociación colectiva respaldaba los fueros de la justicia conmutativa contractual y amortiguaba las conmociones de la paz social. Cuando decae la tesis de los derechos adquiridos colectivamente -en el transcurso afortunado de las relaciones de trabajo- y la crisis se adueña de los ciclos productivos afectados por el desabastecimiento de las materias energéticas, la contribución sindical redunda en sacrificios y renuncias. A cambio de soportar la quiebra del principio de irregresividad, el sindicato ayuda a repartir equitativamente las ofertas de trabajo en el mercado de libre concurrencia y a mitigar la destrucción del bien escaso en que se ha convertido el empleo. El sindicato asiente a las innovaciones tecnológicas, que afianzan la continuidad productiva, y a las variantes de movilidad que ajustan las demandas de ocupación a las incidencias sobrevenidas de la oferta. Acepta que el Derecho Social primitivo -confiado en aprovechar indefinidamente las circunstancias de prosperidad que acompañaron al naciente Estado social y democrático de Derecho- dimita de su triunfalismo de origen y adquiera la fisonomía de un Derecho Social redefinido en función del empleo. El sindicato accede a reemplazar la rigidez de las relaciones de trabajo -vinculadas al ritmo de progreso que expresaba la máxima “siempre más nunca bastante"- por el espíritu de flexibilidad que, para compensar el perjuicio causado por la llamada desmonetización de la negociación colectiva, abre otros frentes a la Política Social y, por vez primera, impone a los trabajadores contraprestaciones especiales de productividad. Las organizaciones sindicales supervisan el ejercicio del derecho-función que, para impedir la desintegración del mundo in- 
dustrial, conviene a una libertad de empresa renovadora y arriesgada. El aprovechamiento de las medidas oficiales de estímulo inversor apareja la carga empresarial de combatir la reducción del empleo y restaurar la parte de su oferta que se ha desmantelado.

Tal es el desplazamiento - muy notable- de los centros de gravedad que caracterizaba al sistema de las relaciones de trabajo.

\section{Notabilidad de la doctrina favorable al papel de suplencia que puede desempeñar el sindicato en cuanto a la presencia social y el ejercicio de las funciones de los partidos políticos}

El pluralismo político -emplazado por el art. 1.1 CE en la órbita de los valores superiores del ordenamiento jurídico- presupone que sus corrientes catalizadoras contienen ingredientes diferenciales y elementos comunes. Dependientes de sus respectivos cuerpos de doctrina y continuidad reflexiva, también son tributarias del espíritu de la legalidad fundamental -que les transmite su voluntad omnicomprensiva de servicio- y de la elasticidad de sus principios y preceptos. Algunos de éstos permiten que los conceptos jurídicos indeterminados -yacentes en sus mandatos y prohibiciones- se incorporen a mensajes acordes con sendas formulaciones pluralistas. Las iniciativas sindicales suplen, si lo intentan oportunamente, la imposibilidad -ajena a los hábitos de los partidos políticos- de colmar el depósito de igualdad y libertad en el que el art. 1.1 CE invita a derramar los recursos disponibles de la justicia material.

La práctica política se atiene a un canon de sustancial enemistad, sin cuyo fiero entrenamiento los días de su supervivencia están contados. El adversario político que, abundando en ingenuas concesiones morales, deja de comportarse como un enemigo despiadado, lleva todas las de perder en el palenque de la confrontación. La realidad es así de desconsoladora y afrentosa. Esto empero, suele acudirse a versiones menos agresivas que las que exhuman las verdaderas tensiones de un antagonismo irreductible. Pese a la reciprocidad de la animadversión que acrecienta, envenena y encoleriza sus contactos, ciertas posturas de los partidos políticos parecen moderar la crudeza de una enemiga irreconciliable con las flaquezas amistosas. Los ciudadanos de a pie descubren el engaño y no recatan la contrariedad que dicho hallazgo les produce. Cabe que, en el ejercicio del poder político o de la oposición que le controla, los partidos institucionales -cautivos del pavor que agarrota su sensibilidad moral-silencien o desfiguren circunstancias que, amén de su enjundia económica y política, condicionan -puestos a imaginar- los inminentes resultados de una contienda electoral. El abuso del pluralismo político y el desprecio de las expectativas de los electores, legitima a estos últimos para revocar la confianza que su ingenuidad depositó en unas verdades ensombrecidas por la irrefrenable enemistad de cuantos las deforman o sustituyen por peligrosas verdades a medias. 
La ausencia de mandato imperativo y las comprobaciones históricas avalan esa desconfianza. La letra y el espíritu del art. 6 CE no deparan a los partidos políticos la oportunidad de reaccionar con la celeridad y lucidez obligadas en ciertas coyunturas. Abundan los encorsetamientos que fomentan esta rigidez y aumentan los recelos sobre su eficacia. Las formas de la democracia delegada no sirven siempre a la sustancia de la justicia material, porque la adulteran y rinden un flaco servicio a cuantos -estupefactos y maniatados a la vez- no dan crédito al relato de sus anomalías. Los orígenes de la democracia totalitaria anticipan la crónica de un calvario anunciado que refleja el tránsito de las formas ordenadas y rectas de gobierno a las inconfesables y corruptas. Súmanse a ello los pactos de silencio que sustraen los abusos al control de una Historia desprovista de datos para mantener un cuerpo de información veraz y puesto al día. Hace falta una resistencia sobrecogedora cuando, al pervertirse el funcionamiento de los sistemas democráticos y desatarse los horrores que causa su comprobación, la vida pública se encuentra inundada- como si la surcasen embarcaciones de corto recorrido y gran frecuencia de circulación - por la infinidad de mentiras a las que se reserva la etiqueta indulgente de modestos pecados veniales.

La naturaleza y la estructura sindicales inducen a enmendar estas situaciones. Otra cosa es que el sindicato resuelva utilizar cuantas opciones le depara el ordenamiento jurídico o muestre parco interés en recurrir a ellas. Sus oportunidades de reacción, la coordinación de sus elementos personales y reales, el deseo de acaparar la estima de las opiniones públicas, la convicción de no ejercer una política de brazo encogido, la inmediata atención de las peticiones de la ciudadanía y la consciencia de que procede unificar, si ello procede, los frentes de combate, facilitan la conversión del sindicato en un agente distinguido del valor superior del pluralismo político.

El art. $6 \mathrm{CE}$ declara que este pluralismo se expresa mediante la acción de los partidos, pero dista de prejuzgar que sean ellos sus exclusivos portadores o que monopolicen las actitudes de respeto que encarece el art. 1.1 CE. El sindicato deviene sujeto activo de un pluralismo político que opera cuantas veces contempla las vicisitudes de un interés determinado y -estimándole digno de sus oficios protectores- le otorga la asistencia de su fuerza social. Ello le habilita para entregarse a las tareas de promoción y defensa que el art. $7 \mathrm{CE}$ tiene a bien asignarle. Como la contribución no es cooperación cuantificada y sí un conjunto de deberes de atención y cuidado, los sindicatos pueden entregarse, sin reticencias ni reservas, a salvar las tibiezas y omisiones de los partidos políticos. Su mediación -integrada por actuaciones espontáneas, acordes con la naturaleza de las cosas y arregladas al ritmo que les cumple-- presupone la eficacia, no el testimonio escueto, de sus medios, y la proscripción de cuanto suene a improvisación o veleidad. La deuda de un sindicalismo ilustrado -fiel a las exigencias de su puesta al servicio de la sociedad-reposa en estas consideraciones. 
Arrostrando las incomodidades del amor a la verdad, los mensajes de los sindicatos denuncian las disfunciones históricosociales y proponen las soluciones aptas, a su juicio, para enderezarlas. Cursan sus llamamientos a una opinión pública dispuesta a secundar los ecos de la conciencia colectiva y a la que otros portadores del valor superior del pluralismo político pueden dejar de informar con la exactitud esperada de su cooperación. El art. 6 CE declara que los partidos políticos concurren a la formación y manifestación de la voluntad popular, pero, si desatienden estas obligaciones naturales, el clamor de la cláusula transformadora y social del art 9.2 CE convoca al sindicato -erigido en poder cuasipúblico- a la tarea de salvar las omisiones advertidas.

Estas y otras reflexiones, compartidas por la Politólogía, avalan la propuesta de que -siempre a la luz del art. $7 \mathrm{CE}$ - las organizaciones sindicales suplan todas o algunas de las intervenciones que, siendo de su incumbencia y pudiendo intentarlas, los partidos políticos se abstienen de emprender y proseguir para realizar sus finalidades específicas. Caducan, según ello, la dependencia y el buen obedecer que la teoría de la correa de transmisión puso en boga. Los partidos políticos soportan servidumbres que, como la mención recurrente del consenso y el diálogo, conviven con el virus antisocial de su enemistad incombustible. Las injerencias -tempestivas y honestas- de la autonomía sindical pueden y deben cooperar a restaurar no pocos estados de cosas que se han tornado infecundos e ingratos. Distinto es que, abrumado por un entorno panorámico de luces y sombras, el sindicato no se atreva a aceptar el desafío y asumir los compromisos de sustitución y/o de suplencia que el reparto constitucional de la justicia material pone a su cargo.

\section{Hostilidad que el fenómeno mundializador desencadena frente al afán de recobrar la autenticidad e integridad de las libertades sindicales}

La mundialización ha dedicado parte de su esfuerzo a desacreditar las virtudes civiles de la Política Social y devaluar las adquisiciones del Derecho fundado en los principios informadores de la misma. Actitud explicable cuando aun se esperaba de los sindicatos una ofensiva de retorno al paraíso perdido de la prosperidad productiva y la plena ocupación. La mundialización de la Política Social -avivada por las prácticas abusivas de la flexibilidad, destructoras de su morigerado ejercicio, y por la terquedad desrreguladora del neoliberalismo salvaje- dio lugar a que los portadores de los intereses económicos, alejados geográficamente de los sindicatos, volaran los puentes de comunicación con sus naturales interlocutores. Neutralizaron el mordiente del conflicto industrial y dejaron herido de muerte el núcleo invulnerable de la autonomía colectiva de dichas organizaciones. Las despojaron del apoyo preciso para aplicar las normas de su ordenamiento jurídico -concurrente con el Derecho del Estado- y asegurar un mínimo intangible de popularidad y prestigio. 
Las libertades de establecimiento y circulación de capitales se suman a estos impedimentos. Si la mundialización tiende a depredar el contenido esencial de las libertades sindicales, el sindicato sólo cuenta con los intentos, escasamente venturosos, de paliar algunas de las afrentas dirigidas a apurar el proceso de su marginación. La magnitud y frecuencia de las libertades -que el capital ejerce sin sentido de su autolimitación- chocan con las dificultades de movilización de los agentes sindicales y coartan el despliegue de sus actividades fuera de las fronteras de los Estados soberanos de origen. Los sindicatos asumen funciones modestas que achican o excluyen su papel dominante -de antiguo indiscutido- para formular las cláusulas colectivas de grueso calibre. Poco o nada tienen que hacer en los ámbitos que, arrebatados a la negociación colectiva por el poder capitalista de organización y dirección, anulan la ilusión de recobrar la irreversibilidad de las conquistas sociales. A semejanza del sigilo agresivo sobre el impacto de las técnicas racionalizadoras en los procesos productivos de antaño, la mundialización de hoy día castiga al sindicato con una plaga de calamidades globales. De ellas forman parte la opacidad de los hechos macroeconómicos, de sus previsiones cognoscibles y de las innovaciones tecnológicas que se suceden con celeridad espasmódica. Su secretismo -que deja indefenso al sindicato- disipa la esperanza de volver a ocupar los que fueron paraísos heroicamente conquistados y lucen hoy la desoladora etiqueta de paraísos perdidos.

Los enclaves geográficos de los ciclos productivos se trasladan a zonas donde -sin precedentes sindicales de espíritu crítico- subsiste una tradición cultural de atonía para censurar las demasías del poder de cualquier índole y resistir frente a sus demasías. Marginada la acción sindical, los poderes económicos deciden degradar, sin un ápice de mala conciencia, los niveles de tutela social que los ordenamientos jurídicos de los países descolonizados iban perfeccionando paso a paso. Algunas instancias políticas han elogiado la voladura controlada de los avances de la Política Social y la disgregación del Derecho Social que, tras configurar el alma y el cuerpo de las libertades sindicales, alimentaba la confianza puesta en la bondad y el éxito de su contribución.

Desvahidas las perspectivas optimistas de las acciones sindicales, se dividen las opiniones sobre el futuro de la contribución transformadora que diseñan los arts. 7 y $9.2 \mathrm{CE}$. El papel del sindicato desmerece en los planos individual y colectivo, pues -al dictar los empresarios unas condiciones de empleo en que la voz sindical ya no pronuncia la última palabra- los trabajadores se resignan al experimento de escalofriantes discriminaciones que recuerdan ocurrencias de la época de la colonia. Protagonizan las situaciones de conflicto impropio que rompen las amarras de la solidaridad horizontal y les entregan a la inclemencia de una navegación desorientada y cautiva. Los eufemismos del cansino concepto de diálogo social demuestran que -sin conciencia de entendimiento y de progreso- las relaciones Estado-empresariado-sindicatos pueden compartir, a lo sumo, los hábitos visibles de 
comedimiento y cortesía, pero ni de lejos acreditan la unanimidad reveladora de un sincero propósito de cambio. Poco o nada importa que el sindicato siga sirviendo a los fines sociales de que, en su tiempo, fue un positivo valedor, ni que garantice los contactos en que el efecto del concurso de fuerzas -aprisionado por las servidumbres económicas- sólo anticipa la certeza de conseguir bastante menos de lo que se ha llegado a prometer.

\section{Diseño constitucional de los modos con que la contribución del sindicato provee a la suerte de los intereses legítimos que, como propios, viene obligado a promover y defender}

El uso que de los términos promoción y defensa hace el art. $7 \mathrm{CE}$, revela la maleabilidad semántica con que el constituyente enfoca la fenómenología de los acontecimientos sindicales. Promover es, en una de sus acepciones plausibles, traer a capítulo - para dejar constancia fidedigna de ello- una situación conocida que, pese a lo valioso de su supervivencia, decae aparatosamente o deja de atraer el interés de los obligados a tenerla presente. La debilidad de las capacidades de acción y de reacción sindicales disminuye el peso específico de sus organizaciones. Nada más parecido a la suerte de unos muertos vivientes que, a duras penas, conservan la esperanza de la resurrección. Los sindicatos saben de la entidad del mal que les aqueja y les remuerde la evidencia de que, estando ahí, no han acertado a preservar la imagen -aseada y duradera- que les correspondía promover. La promoción recuerda que ha fallado algo imprescindible para el éxito de las aventuras sindicales, porque se ha errado al repartir los papeles que ha de representar un sindicato acuciado por las premoniciones de una inclemente toma de conciencia. La promoción constituye un mecanismo de rescate pensado para restituir al universo sindical los bienes o valores que, perteneciéndole de antiguo, se han evadido de sus reductos de tutela y, al rebajar su integridad, se echan en falta. Restaura la identidad de los intereses degradados o que están a punto de correr la más indeseable y desventurada de las suertes. La promoción consiste en actos de conservación que, como las categorías afines del Derecho Privado, no combaten las agresiones de rostro visible, pero se empeñan en luchar contra el olvido que -de puntillas e inexorablemente- traiciona su memoria.

Otro sentido de la promoción llega más lejos del examen de la naturaleza de las cosas que apunta la acepción indicada. Los elementos contextual y sistemático de interpretación -que alberga el art. 9.2 CE- revelan la importancia de considerar los intereses propios del sindicato como objetivos óptimos del esfuerzo de transformación. Promover es mejorar la cantidad y calidad del apetito que - en cuanto inseparable de la condición humana- va en pos de los bienes sensibles de la vida. Es ensanchar la zona de mejora de los intereses y excitar la intensidad con que la opinión pública debe entregarse a cultivarlos. Así se adjudican los intereses desnudos - propugnados por los sindicatos portadores-o los intereses vestidos por las normas jurídicas del Derecho Positivo 
que incluyen los derechos procesales de acción y de excepción. No se reacciona aquí contra el olvido, sino contra el error de dar por satisfecho un interés que, hurtándose a la tentación transformadora, pierde una de las oportunidades generosas que, para hacer Historia de la buena, ofrece al sindicato el legislador constituyente.

Sutilmente distinta es la defensa del interés encomendado a la solicitud del sindicato. El interés acompaña a las actividades sindicales y se alimenta de los incentivos que aportan las variantes de su promoción. Ni la pasividad de sus portadores pone en peligro su existencia, ni el olvido es la causa de los riesgos a que se encuentra expuesto. Las actividades sindicales admiten formas admirables de cooperación y soportan las embestidas tendentes a demolerlas y/o restarles el prestigio costosamente conseguido. La defensa de los intereses propios -necesitada, como enseña el art. $7 \mathrm{CE}$, de otros contingentes de refuerzo- suscita animadversiones que agrietan, desde el exterior, la entereza del universo sindical. Las agresiones directas o indirectas pueden atentar contra los intereses arraigados de antiguo, contra los tempestivamente recobrados -si estuvieron a punto de desaparecer y/o evaporarse- y contra los remozados por los aditamentos que introduce el sindicato innovador.

El interés consiste en el vehemente afán de conseguir la utilidad de bienes y/o valores aprehensibles con los medios que el Derecho objetivo dispensa a cuantos exteriorizan la voluntad de hacerlos suyos. La noción de intereses generales, referida en el art. 103.1 CE, conviene a todos los grupos componentes de la sociedad pluralista, si su magnitud así lo da a entender, o a las comunidades individualizadas por sus respectivos rasgos diferenciadores. Los intereses generales y los particulares se protegen extrajudicialmente -con los medios que sus portadores seleccionan y emplean-o a través del moderno derecho fundamental que el art. 24.1 CE ha introducido bajo el nombre de tutela judicial efectiva. Tutela que, según la modestia de su definición en boga, no alcanza los niveles de un esfuerzo de transformación que, para afianzar la supremacía indiscutible de la justicia material, exige valiosos complementos de especificación y garantía.

Los intereses confiados a la promoción y defensa de los sindicatos se consideran propios cuando ya figuran en el marco de sus objetivos notorios oemergiendo en el horizonte histórico de la razón práctica- se suman al cúmulo de sus actividades. La libertad sindical ha de fijar, sin irrazonables restricciones, los términos de la ampliación de esas acciones. No tienen por qué sorprender las decisiones sindicales que, ante el olvido, la desatención o el empobrecimiento de ciertos intereses, se inquietan por su fragilidad y los atraen a la esfera de su protección. Adoptan decisiones cuya dosis de aspiración transformadora obliga a presumir la legitimidad de tal iniciativa. Lo propio designa todo lo contrario de una cortapisa de la actividad del sindicato y abarca, como concepto jurídico indeterminado, el máximo de posibilidades expansivas que apuntan la equidad y la recta sazón, sin sujetarse a un repertorio de competencias sindicales tasadas por quién sabe qué intérpretes de la 
voluntad social. De ahí, la discrecionalidad con que, gracias a sus prerrogativas de privilegio, las vanguardias sindicales invaden las parcelas que delimitan los imperativos - morales y sociales- del momento y de las que les apremian a entrar en posesión. Intentan mejorar la suerte colectiva o colmar los afanes de quienes, sin haber dejado atrás toda esperanza, siguen creyendo en los empeños morales de renovación y en las capacidades técnicas precisas para gratificar los entusiasmos del espíritu de cambio.

El sindicato promueve y defiende los intereses propios mediante la $\mathrm{co}$ participación, una parcela del interés general que las comunidades seculares equiparan a la noción de bien común heredada de la tradición aristotélicotomista. Sus propuestas obedecen a una sana razonabilidad -destello de las demandas sociales genuinas y no deformadas- y a una detenida comunión con el aprendizaje de la naturaleza de las cosas.

El sindicato se apropia de intereses económicos y sociales Lo económico atañe a la condición profesional -dominada por el factor-capital en la organización de las relaciones de trabajo- y designa la capacidad del sindicato para que, sin alienarse en diálogos de sordos o estériles monólogos unilaterales, entre en contacto con los centros de decisión oficial en materia de Política Económica. Lastimosamente, se tarda demasiado en sopesar ciertas razones que se conocen y valoran cuando han quedado atrás las circunstancias propias del tiempo y del lugar en que estaban llamadas a surtir efecto. La opinión pública no ve con buenos ojos que la censura sindical critique las conductas de los empresarios con acritud mayor que la empleada al reprobar ciertas acciones de las instancias oficiales que -salvo en las escenas amañadas de severidad o desacuerdo- gozan de una indulgencia inmerecida. Este temor reverencial no se condice con la rabiosa independencia que, en pro de su credibilidad, debe acreditar un sindicato deseoso de contribuir, sin dilaciones ni falacias, a la producción de los cambios sociales.

Se estiman intereses sociales -acreedores a la promoción y defensa con que se les distingue- los asumidos por los grupos que, según el art. 9.2 CE, congregan a las personas físicas y a los restantes pobladores de la sociedad pluralista. El sindicato ha de velar por sus necesidades, pues, como poder cuasipúblico que viene a ser, le incumbe fomentar los valores superiores de la igualdad y la libertad efectivas. Su selección depende de la autonomía sindical que, una vez encontrados, ha de elegir el mejor modo de satisfacerlos, sin confundir la libertad con los espacios residuales que deja tras de sí la incompetencia de los poderes públicos. Se trata de intereses notorios-que, por primera vez, aguardan la protección que no tenían- o de intereses emergentes, cuyo reclamo excita la curiosidad del sindicato y, a la luz del derecho-función extraído del art. $7 \mathrm{CE}$, engrosa el catálogo de sus obligaciones naturales.

Bajo la rúbrica De los principios rectores de la Política Social y Económica, objeto del desarrollo legislativo ordinario que anuncia el art. 53.3 CE, el cap. $3^{\circ}$, tít. I CE formula una lista provocadora y abierta de grupos sociales significativos. Su enunciado recuerda al sindicato-preparado para los 
lances de su promoción y defensa- la eminencia del esfuerzo de transformación y la prioridad de los compromisos anejos a sus ambiciones. Una comunidad - presente o futura-puede sentir estas necesidades desde que acaece su entrada en escena o en cualquiera de las ulteriores peripecias que, delicadamente analizada, le obligue a tomar partido y definirse en consecuencia.

El encabezamiento del pasaje cuida de citar la Política Social y Económica, que es una Política bicípite, y no sendas Políticas, Social, la una, y Económica, la otra. Al sustantivo Política -estampado en número singularle siguen los dos adjetivos que, enlazados por una conjunción copulativa, generan el concepto subyacente al rótulo que le localiza. La Política Social y la Política Económica no se escinden ni erigen en materias respectivamente gobernadas por los principios rectores cuyas funciones enumera el art. 53.3 CE. El texto en cuestión no reza De los principios rectores de la Política Social y de la Política Económica. Los principios propuestos y sus desarrollos legislativos no se satisfacen con sólo la actuación de las facultades de sus beneficiarios, pues requieren acciones complementarias exteriores que, al robustecerlos, les confieren efectividad. Ello ha de ser obra de la diligencia con que otros promotores del bienestar social, singularmente los poderes públicos, gestionan los gravámenes de la transformación y manejan los recursos -personales y reales- sin cuya aplicación fracasa la confianza puesta en los anuncios del espíritu de cambio.

La defensa de la propiedad -protectora de las apariencias del hecho posesorio- descansaba en la presunción de que casi todos los poseedores eran propietarios, aunque se beneficiase a unos cuantos - los menos- que carecían de derecho de dominio sobre los bienes poseídos. La extensión de la cobertura sindical a los intereses de las comunidades que no gozaban de ella, obedece a la presunción de que mayoritariamente están pobladas por trabajadores dependientes de los sectores público y privado. Además de promover y defender los intereses de estos últimos, la presunción cobija el interés colectivo de los componentes minoritarios del grupo que, sin ser trabajadores, participan de las expectativas generadas por la difusión del ofrecimiento sindical.

\section{Envergadura, proyección y difusión de las actividades de contribución sindical}

La libertad sindical -plasmada en la ampliación de sus progresivas funciones históricas y en las conductas de sus titulares- es la protagonista eminente de las relaciones colectivas de trabajo y el emblema de la autonomía colectiva que descansa en la cláusula dúctil del art. $7 \mathrm{CE}$. Al concebirse toscamente el carácter de las reivindicaciones sindicales como episodios de alteración del orden público, la voluntad de sobreproteger el derecho pleno de propiedad privada y los derechos reales restringidos de goce y garantía, llevó a la incriminación -desproporcionada y efímera- de aquellos movimientos, sucedida luego por la represión contractual de los intereses sociales que en- 
carnaban. El problema se trasladó al campo de las relaciones individuales de trabajo, sancionándose con el despido el incumplimiento imputado a las nacientes acciones del sindicalismo. Los interregnos de los regímenes autoritarios aderezaron la teoría de las comunidades nacionales de capital y trabajo, proclamando, contra el demoliberalismo decadente, su encarnizada determinación de liquidar la lucha de clases y reemplazarla por los elementos patrióticos de colaboración. Proscribieron la figura del sindicato que internacionalizaba los problemas compartidos por las clases sociales cuyos intereses amparaba. Erigida la figura del Estado social y democrático de Derecho y constando el mérito de sus innovaciones, penetró el espíritu de modernidad que animaba una voluntad de perpetuación y crecimiento. El Estado favorecía la instalación del sindicato -unión personal carente de sustento físico- en el espacio territorial de su soberanía política. Le obligaba un principio general del Derecho de Gentes que, asumido por los países industrializados con economía de mercado, requería cumplir, sin fisuras, los compromisos contraídos con las causas cuyo apoyo y control le competían desde entonces.

No habría estado de más que, en vez de aludir genéricamente al ejercicio de sus actividades y mejorando la incompleta dicción del art. 28.1 CE, el art. $7 \mathrm{CE}$ se hubiese referido a las libertades sindicales individuales y colectivas.

La libertad sindical individual habilita a la persona física del trabajador para integrarse voluntariamente en las organizaciones protectoras de su relación contractual y de cuantos intereses merezcan, en opinión del sindicato, sacrificios equitativamente compensados. De su contenido esencial-revitalizado por el cumplimiento de los deberes de contribución-forman parte los derechos a pactar las condiciones de empleo, extinguir voluntariamente el contrato de trabajo y compeler, si es del caso, el decisionismo empresarial. Derechos que se identifican como iguales a si mismos y se reconocen conforme a la naturaleza de las cosas. Vistos los arts. 22.1,36, 52, 127.1 y $131.2 \mathrm{CE}$, se asemejan a la libertad sindical los derechos de asociarse, adscribirse a organizaciones profesionales, pertenecer a corporaciones, vincularse a las nuevas formas de sindicalismo e insertarse en organizaciones económicas.

La libertad sindical colectiva actua unos derechos históricamente acreditados y ampara cuantas situaciones - preexistentes o surgidas de súbito en la vida social de relación- el sindicato decide proteger. La libertad sindical negativa no acelera el ritmo de los fenómenos del cambio ni aproxima a las metas del esfuerzo de transformación igualitaria, colocándose al margen de los comportamientos solidarios en que su omnipresencia debe vigilar las promesas combativas de liberación.

La devaluación de las libertades sindicales individuales y colectivas ha registrado una trayectoria desalentadora y a la que el sindicato no se ha opuesto con la energía esperada de sus capacidades de respuesta. So pretexto de situaciones críticas deficientemente gestionadas, se ha esfumado el principio de irregresividad de las adquisiciones sindicales. Se ha abusado del dogma de la 
flexibilidad que, para espolear las funciones sociales del capital y no para privilegiarle, se añadió al contenido esencial de la libertad de empresa. Las apariencias de flexibilidad refrendaron excesos tecnológicos que, más allá de sus objetivos plausibles, minaron los derechos centrales de los trabajadores. Las reconversiones industriales salvajes suplantaron las fórmulas equitativas de rehabilitación productiva y readaptación profesional. Despreciando la fortaleza de los sindicatos, se les ha obligado a dar por buenos los paliativos de las crisis cuya existencia y magnitud se han ocultado, mintiendo escandalosamente, por motivos políticos, y engañando a la sociedad que se ha enterado tardíamente de la enorme recesión económica que arruinaba su estabilidad y su futuro.

El sindicato sufre los daños de la globalización que, al dispersar territorialmente los factores productivos, desploma las bases de la distensión del conflicto industrial. Pierde las batallas libradas contra los deterioros que esa disociación ingiere en el presente y el futuro del mundo del trabajo. Encaja las agresiones que relegan parte de las actividades sindicales a oficios secundarios o de mera gestión. Se encuentra inerme para evitar los conflictos horizontales que generan, entre trabajadores, el control empresarial de las condiciones de trabajo y las discriminaciones divisorias en que se materializan sus abusos. Presencia cómo estas escisiones evaporan la conciencia de clase que cede su lugar a sucedáneos irreconocibles. Repara en la avidez con que las jugadas maestras neoliberales no ven llegado el momento de reprivatizar el Derecho Social y demoler el edificio alzado por la sensibilidad y el talento de sus descubridores.

Este desvanecimiento gradual -al que la tecnología demoníaca suma elementos que ensombrecen aun más su panorama- era el reverso del criterio que, antes de estrenarse la fórmula binómica de control-apoyo, rehusaba al sindicato el carácter de centro de imputación o persona jurídica responsable de sus comportamientos. La doctrina de la inmunidad del sindicalismo radical sostuvo que, en virtud de su propensión expansiva, las peripecias y los comportamientos de las organizaciones sindicales escapaban al control de los poderes públicos. Los arts. 1.1, 7, 9.2, 10.1 y 103.1 CE mudan esta caústica proposición, evidenciando que las opciones de progreso -que los sindicatos hagan suyas- se sujetan a las limitaciones impuestas por el concurso de los intereses generales.

Junto a sus ingredientes fiscalizadores, el contenido esencial o núcleo invulnerable de la libertad sindical colectiva incluye una autonomía general subdividida en iniciativas naturales. A saber, el ejercicio de las potestades normativas interiores del sindicato, las actuaciones determinantes y definidoras de su arraigo o asociadas a las especies representativas, la defensa de su gestión frente a las perturbaciones externas de hecho o de Derecho, la negociación colectiva generatriz del ordenamiento jurídico extraestatal, el alcance de las medidas autotutelares que cabe adoptar, la facultad de disolverse voluntariamente y la oportunidad de integrarse en federaciones o confederaciones 
sindicales. Subsumibles, todas ellas, en el concepto jurídico indeterminado de objetivos propios que presenta el art. 7 CE.

La autonomía sindical es más enérgica que el diálogo social expuesto al voluntarismo veleidoso o a la velocidad de crucero de sus protagonistas. Aloja un ejemplo -falsificado cuando se interrumpe- de flujo social, en que la movilidad, incluso imperceptible o apagada, de los sindicatos produce acciones o reacciones a cuyas consecuencias no escapan los otros agentes de aquel diálogo, aunque la interlocución se adormezca o esté paralizada. El universo de estas relaciones evoluciona espectacularmente y de continuo.

Para tomar razón del cambio, hacen falta unas dotes de perspicacia con las que no siempre se cuenta y un conjunto de datos de escabrosa verificación. La historia de la libertad sindical no puede descansar en una información superficial sobre actitudes públicas que, pese a su notoriedad, no erosionan la superficie de las cosas ni ayudan a su cabal conocimiento. Los cuadros generales de demostración del Derecho Público y el Derecho Privado desesperan de sacar a flote lo que, trascendiendo a la creación y aplicación del Derecho Social, proviene de esas interioridades. La Politología ha descubierto que la aparente solidaridad de las intenciones públicas, en tema de Política Social, esconde temibles zonas de doblez -plagadas de malas intenciones- respecto al presente y el futuro del mundo del trabajo. Al nominalismo del diálogo social subyacen disidencias hondas -que antaño ya hubiesen movido a la revolución- sobre problemas que se han petrificado, porque ha pasado el tiempo de plantearlos o a los que, para aplazar indefinidamente su resolución, se destituye de su natural importancia. Se confirma el temor de que, a la larga, los compromisos cualitativos de los sindicatos resultan vencidos por el entusiasmo consumista de las que fueron sus amistades peligrosas.

La Sociología está dispuesta -en pie de guerra- a inventariar y dar noticia de los hechos sociales significativos que encajan en tan convulso panorama. Bajo la vestidura de anuncios blandos y apacibles, las voces de la Economía difunden consignas de inmisericorde dureza. Las innovaciones tecnológicas sirven más tenazmente a los fueros del economicismo, que a la preocupación antropocéntrica de las libertades sindicales. Ciertas corrientes en boga de la moralidad secular y algunos particularismos religiosos de hoy día oscurecen -como en la más tenebrosa de las noches- la claridad de las visiones que auguraban el venturoso porvenir de los avances sindicales. Aunque luchan contra viento y marea, estas actividades dependen de una fenómenología -fruto de la heterogeneidad de sus variables- que poco o nada les ayuda en el curso de sus desencuentros.

La crónica de la evolución del Derecho Social y de las Políticas Sociales que han inspirado su progreso, se escribe con los renglones torcidos de versiones melladas e incompletas. Haría falta un súbito milagro para recuperar la integridad y transparencia de esos episodios, retransmitiéndolas a cuantos mantienen la voluntad de conocerlas y acceder a las filas de los ejércitos anónimos que arriesgan su suerte frente a unos males e injusticias que amenazan 
con no acabarse nunca. Sigue, en definitiva, siendo misión imposible la tarea de denunciar tanta mentira como la que, escamoteando la verdad de semejantes realidades y echando agua en el mar, enardece por doquier la ira de los justos.

\section{9. ¿Se aprecia algún reciente testimonio de la voluntad transformadora del sindicato democrático?}

Una experiencia sociopolítica reciente invita a pronunciarse sobre la medida en que el modelo de sindicato del Estado social y democrático de Derecho -patente en el art. 1.1 CE- ha acomodado su conducta al espíritu de cambio y conseguido efectos consecuentes con esa aspiración. ¿Hasta dónde ha podido o querido llegar su idoneidad transformadora en las peripecias que seguidamente se mencionan?

La huelga general se significa por el dato de que - suspendidas, a causa de su impacto, las relaciones de apoyo y control que vinculan al Estado con los sindicatos democráticos instalados en la esfera geográfica de su soberaníala acción excepcional de los segundos disuelve, mientras perdura el estado de huelga, la compacidad de las comunidades que forman la sociedad pluralista. La imposición da lugar -en fe de la efectividad de un poder superior al de las instituciones oficiales que sufren su agresión- a la cesación o reducción lesiva de los servicios esenciales de la comunidad que refieren los arts. 28.2 y $32 \mathrm{CE}$. Servicios que - emanados de los poderes públicos o de los titulares del derecho a la libertad de empresa en una economía de mercado- subvienen a las necesidades cuya desatención disloca la sociedad y la convierte en una colectividad deslavazada e inorgánica.

Cuando la huelga general combate algunas actitudes del poder político, tiende a reemplazar ciertos efectos de su decisionismo -supuestamente dañosos para los intereses generales de los trabajadores- por una reflexión sobre la enjundia del problema y las soluciones que, en vista de un nuevo panorama, exhuma el planteamiento sindical. Se patentiza la temibilidad de un poder, irreductible en sus posturas de coerción, y se alecciona a la ciudadanía -más o menos interesada en el problema- sobre la relevancia de las finalidades defendidas. Hay una suerte de premonición que -usando de una simulación pedagógica provisional- insinua la pertinencia de un cambio en que la acción de los partidos ceda su lugar al acaparamiento sindical de las iniciativas políticas y de las manifestaciones de la voluntad popular.

La huelga general, como medio proteico de autotutela sindical, implica que la sociedad pluralista -formada por grupos que acopian una dosis de organización y de poder merecedoras de tenerse en cuenta-sufre la novación revolucionaria del regular funcionamiento de las instituciones paralizadas por la obstrucción de los huelguistas. Estos operan con la finalidad didáctica de difundir que, agotadas las armas de la reflexión cauta y el convencimiento razonable, su voluntad de coerción inmediata puede más que los elementos co- 
ercitivos con que el Estado democrático garantiza su permanencia y unidad. Se introduce un estado de no exigibilidad de otra conducta -por el que decae temporalmente la consigna central del Estado de Derecho que formula el art. 9.1 CE- para demostrar que el TPCE concilia los presupuestos clásicos de aquél con las influencias de la moralidad legalizada. La sociedad organizada en el Estado retrocede y su condición de comunidad racionalizada se encuentra herida de un mal de dispersión. El poder político -arrinconado por las demostraciones de fuerza del poder sindical- carece de recursos para restaurar los aspectos de la vida social que la cesación concertada del trabajo -en que la huelga general consiste- sustrae a sus regulaciones. El sindicato intenta convencer de que, si sus pretensiones no prosperan y hay que aumentar la dosis de presión empleada para aderezarlas, puede congelar los servicios esenciales de la comunidad y ocasionar graves desperfectos sociales.

La huelga general aludida guardaba semejanza con las que los sindicatos de algunos países europeos habían preparado, tiempo atrás, contra los dictados de la UE que -como parte del orden público o Derecho necesario de las comunidades- intimaban a observar los requisitos de reducción del déficit y de la deuda pública. La huelga pretendía obtener la misma eficacia con que otras acciones interiores de autotutela sindical habían obligado a los poderes públicos a desistir de sus proyectos neoliberales de reforma. El poder sindical movilizó todos sus recursos y prejuzgó -- con error calculado o escasez de visión- que el prestigio de los sindicatos se robustecía si se daban efectos similares a los de aquellos precedentes. No contaba con otras variables que complicaban su consideración analítica.

Mediaba un defecto de asistencia, porque, pese a la espectacularidad de la convocatoria, ésta sólo se secundó por menos de una tercera parte de los llamados a participar en la huelga general. Si la voluntad sindical había forzado, en ocasiones anteriores, la renuncia de una voluntad oficial que era libre de hacer o no hacer, la huelga general se promovía contra unas normas de Derecho Positivo inmunes a las propuestas sindicales. Se pretendía soslayar el imperio de un Derecho de Gentes -repentino, confuso, difuso y proveniente, a oleadas, de la UE- que, como parte del ordenamiento jurídico comunitario, avalaba la indisponibilidad del orden público virtual del espacio social europeo.

A las desacertadas previsiones sobre la contundencia del poder sindical y el buen fin de la convocatoria, se sumaban motivos bastantes para empañar la perspectiva de una huelga general cuyos promotores erraban al calificarla, a los cuatro vientos y sin dignarse hacer memoria del pasado, como la más justificada desde el comienzo de la transición democrática.

Al definirse de este modo y volver contra los propios actos, los sindicatos olvidaban - de la noche a la mañana- que habían sido parte de la maquinaria política contra la que se alzaban estrepitosamente. Algunos de los foros abiertos al análisis de la situación causaban la impresión surrealista de que la huelga no se promovía contra el poder constituido y sí contra conductas im- 
putables a la oposición. La reacción se explica recordando que, con olvido de sus deberes críticos, los sindicatos habían asentido complacientemente a una Política Económica que había originado cifras de paro estremecedoras y bastantes para degradar el crédito de sus reivindicaciones tardías.

Pesaba el lastre de la mala conciencia que se acusaba a la sazón, pues el desencadenamiento de una huelga general -distinguida por lo espectacular de su despliegue y el descrédito que su frustración acarrea- sólo es aconsejable si existe una situación de prosperidad económica que permite augurar el éxito de sus objetivos. Sus probabilidades de triunfar son escasas, por no decir que nulas, si coincide con una estadística de desempleo que, contra lo teatral e inútil de la iniciativa, demuestra la contribución omisiva de los sindicatos a tan desafortunada evidencia.

La escasez de la participación activa en la huelga y su fracaso revelaron -además del castigo moral evocador de esas flaquezas- la desconfianza y el hartazgo de muchos grupos de trabajadores cuyas relaciones contractuales registraban de antiguo la desprotección y/o debilidad más dolorosas.

Pocos preconizaban el éxito de la operación de autotutela emprendida por unos sindicatos que - expertos en fomentar la adjudicación de privilegios y la constitución de castas- se habían abstenido, deliberadamente y sin pensarlo dos veces, de intervenir en debates que abordaban la suerte de los más acuciantes problemas de los trabajadores.

El discurso inspirador de las iniciativas sindicales que incitaron a la huelga general, se correspondía con el pensamiento -pendiente de ponerse al día- de la parte de la representación parlamentaria que profesaba el mismo credo. Se echaba de menos el esfuerzo en modernizar el cuerpo de doctrina preciso para pronunciarse, con suficiente autoridad, sobre las situaciones globales que inducían a esa decisión, señalando las movilizaciones requeridas y previendo, sin imprudentes predicciones, los efectos de la decisión adoptada.

En semejante coyuntura, el poder sindical quiso administrar -con demagogia irrestricta- un estado de cosas que no se condecía con la escenificación convincente de la voluntad transformadora del sindicato democrático. Una voluntad que, al contrario del supuesto objeto de examen, tiene que alimentarse de unos mínimos que presuponen autenticidad, independencia, solidez imaginativa, atracción fecunda de adhesiones, inequivocidad de los objetivos, ausencia de complicidades espurias y modernidad de los métodos y/o razonamientos utilizados.

Más tarde, ha circulado la coartada de que no es del caso, pese a lo anunciado, convocar otra huelga general contra unas reformas cuya ocurrencia no se debe a la creatividad ni a las vigilias de los responsables de la gobernación del Estado- que habrían preferido continuar sus experimentos sin gaseosa- y sí a las condiciones impuestas por el Derecho necesario del orden público europeo. Los sindicatos -deseosos de eludir la puesta a prueba de la energía de su capacidad transformadora- afirman, contra la realidad de las cosas, que, por motivaciones razonables, desisten de utilizar la huelga general como instru- 
mento de transformación. Advierten que, en homenaje al consenso, hay que reemplazar la actuación -visiblemente decaída- de su poder de autototutela por soluciones pactadas con el poder constituido. Un balón de oxígeno que sofocaría el descrédito causado por el descarrilamiento de la huelga general a la que cautamente se renuncia. Silencian, para no empeorar el deterioro de su imagen, que el asentimiento del Reino de España a esa fórmula pacificadora no ha nacido de una determinación libremente adoptada. Omiten que constituye la ejecución de un compromiso contraído por la UE y los responsables españoles asomados al abismo de una quiebra de la economía del país Un acuerdo que dichos gobernantes, puestos entre la espada y la pared, acataron como una capitulación sin condiciones.

Se pregunta si sucesivos episodios -embebidos en la letalidad de la crisis económica e inevitables como tales- darán a los sindicatos la oportunidad de sortear los escollos que arruinan su poder, y de ganar, para edificación de propios y extraños, posiciones de acción transformadora que convenzan de la veracidad de su empuje, del vigor de sus dotes de credibilidad y del éxito de su espíritu de servicio.

\section{Bibliografía de orientación}

BARCEllona, P. et al. L'uso alternativo del diritto. Roma- Bari: Ed. LATERZA, 3 vols., 1.974 .

Bartocci, E. Sindacato, clase, societá. Padua: Ed. Cedam, 1.975.

BENDIX, R. Work and authority. Berkeley: Ed. UnIVERSITY of CALIFORNIA PRESS, 1.951.

Bobbio, N. "Sulla rinascita del Giusnaturalismo", Rivista di Filosofía, pp. 408-410. Padua: Ed. CEDAM, 1.963.

Brown, H. Los orígenes del poder sindical, trad. de Conde, A. Madrid: Ed. Ministerio de Trabajo y Seguridad Social, 1.990.

CAhn, E. The sense of injustice. Nueva York: Ed. New York University PRESS, 1.949.

CERroni, U. El pensamiento jurídico soviético, trad. de ZaPATERO, V. Madrid: Ed. EDICUSA, 1.977.

CotTURRI, G. Sindicatos, aparatos de justicia y demanda social, trad. de CAPELLA, J.R. Barcelona: Ed. FonTANELLA, 1.976.

De LA Villa, L.E. Materiales para el estudio del sindicato. Madrid: Ed. InsTITUTO DE ESTUDIOS SOCIALES, 1.979.

De Vicente, C. Trabajo y Sindicatos, 1.974-1.977. Madrid: Ed. Edicusa, 1.977.

DuBIEFF, F. Le syndicalisme revolutionnaire. París: Ed. FlammARIOn, 1.969. Duverger, M. Sociología política, trad. de Esteban, J. Barcelona: Ed. Ariel, 1.968 . 
Etzioni, A. La sociedad activa, trad. de Fuente, E. Madrid: Ed. Aguilar, 1.980 .

Flammia, R. Contributo all'analisi dei sindacati di fatto. Milán: Ed. GiUfFre, 1.963.

Garcia Abadillo, C. Fracaso de una huelga. Madrid: Ed. El Mundo, 29.09 .10 , p. 5.

Garcia-Pelayo, M. Las transformaciones del Estado contemporáneo. Madrid: Ed. AlianZa UniVERSIDAD, 1.977.

Giugni, G. Derecho Sindical, trad. de Vida, J. y Montalvo, J. Madrid: Ed. Ministerio de TRABajo y Seguridad Social, 1.983.

GoldsMichDt, W. La Ciencia de la Justicia. Madrid: Ed. Aguilar, 1.958.

GoOdMAn, P. The seeds of liberation. Nueva York: Ed. BRAZILLER, 1.965.

JIMENEZ, F. Las cuatro esquinas: Apaño ruinoso Gobierno-sindicatos. Madrid: Ed. El Mundo, 15.01.11, p. 17.

LURIA, A. The nature of human conflicts. Nueva York: Ed. LIVERIGHT, 1.932.

Mancini, G. y Romagnoli, U. Il diritto sindacale. Bolonia: Ed. Il Mulino, 1.973.

PARSONS, T. et al. Toward a general theory of action. Cambridge, Mass. : Ed. HARVARD UNIVERSITY PRESS, 1.952.

PetTa, P. Ideología constitucional de la izquierda italiana, trad. de ClaveRIA, A. Barcelona: Ed. Blume, 1.978.

Rescigno, P. Persona e comunitá. Bolonia: Ed. Il Mulino, 1.966.

Santoro-Pasarelli, F. Saggi di diritto civile. Nápoles: Ed. Jovene, 1.961.

SIMPSON, K. International arbitration: Law and practice. Londres: Ed. STEVENS, 1.959.

Smuraglia, C. La Costituzione e il sistema del diritto del lavoro. Milán: Ed. FELTRINELLI, 1.958.

STERnBerg, F. The coming crisis. Nueva York: Ed. JoHn DAY, 1.947.

TAREllo, G. Teorie e ideologie nel diritto sindacale. Milán: Ed. Comunita, 1.967.

TROTSKY, L. La revolución permanente, trad. de Nin, A. Gijón: Ed. JuCAR, 1.976.

Weiss, D. Política, Partidos y sindicatos en la empresa, trad. de Fz. Miranda, E. Madrid: Ed. Instituto de Estudios Laborales y De LA Seguridad SOCIAL, 1.982 .

Wright, C. The new men labour leaders. Nueva York: Ed. HARCOURT, BRACE and Company, 1.988 .

ZAngari, G. et al. Potere sindacale e ordinamento giuridico. Bari: Ed. DE DONATO, 1.972.

ZorriLla, M.M. Protección judicial de las relaciones colectivas de trabajo. Bilbao: Ed. GOMILEX, 2.009. 